Tarih Kültür ve Sanat Araştırmaları Dergisi

Revue des Recherches en Histoire Culture et Art
Vol. 5, No. 3, September 2016

Copyright (C) Karabuk University

http://kutaksam.karabuk.edu.tr/index.php

\title{
DOI: 10.7596/taksad.v5i3.558
}

\section{Romanların Tüketim Eksenli Yaşam Tarzlarının İncelenmesi: Bursa Şehir Merkezinde Bir Uygulama}

\author{
Ali Çağlar Çakmak ${ }^{1}$
}

$\ddot{\mathbf{O z}}$

Yüzyıllardır aynı topraklarda bir arada yaşadığımız Romanlar, renkli kişilikleriyle ve farklı yaşam tarzlarıyla sosyolojik yapımıza değer katmaktadırlar. Romanların tüketim davranışları ve bu bağlamda yaşam tarzları ile ilgili çok az çalışma yapılmıştır. Bu çalışma literatüre katkı sağlamak amacıyla Roman vatandaşlarının tüketim eksenli yaşam tarzlarını incelemeyi konu edinmektedir. Bursa şehir merkezinde yaşayan Romanlar çalışmanın ana kütlesini oluşturmaktadır. Seçilen örnekleme FIF (Faaliyet, İlgi Alanı, Fikir) Yaşam Tarzı Ölçeği uygulanmıştır. Elde edilen verilere Yüzde Analizi, Mertebeli Dereceleme, Faktör Analizi ve MANOVA uygulanmıştır. Araştırma sonuçları Romanların tüketim eksenli yaşam tarzları ile ilgili önemli detayları içermektedir.

Anahtar Kelimeler: Bursa, Romanlar, Yaşam Tarzı, Tüketim, FİF Ölçeği

\section{Examining the Gypsies Consumption Axis Lifestyles: An Application at Bursa City Centre}

\section{Abstract}

We live together in the same territory for centuries Gypsies, with their colorful personalities and they add value to our sociological structure with different lifestyles. There has been less study about consumption behavior and in this context lifestyles of Gypsies. This research studies the scrutiny to Gypsy citizens' consumption axis lifestyles for contribute the literature. Gypsies which live in Bursa city center are the main mass of the research. AIO (Activities, Interests, Opinions) Lifestyle Scale was applied to the selected sample from the main mass. The data acquired as the result of the survey is evaluated with Percentage Analysis, Staged Grading, Factor Analysis and Single Factor Multiple Variance Analysis (MANOVA). The results of the research includes the important details of the Gypsies consumption axis lifestyles.

Keywords: Bursa, Gypsies, Lifestyle, Consumption, AIO Scale.

\footnotetext{
${ }^{1}$ Assoc. Prof. Dr., Bursa Technical University, Turkey. accakmak1974@gmail.com
} 


\section{Giriş}

Tüketim, insanın varoluşuyla birlikte başlayan bir olgudur. İnsan, dünyaya gelişiyle birlikte gereksinim duymaya başlar. İhtiyaçların giderilmesi hayatın devamlılığı açısından büyük önem arzetmektedir. Faydalı mal ve hizmetlerin insanların ihtiyaçlarının giderilmesi amacıyla kullanılmasına tüketim denir. Tüketim, temelde bütün ekonomik faaliyetlerin nihai amacıdır. İnsanların yaşam düzeylerinin yükselmesinin en önemli göstergesi daha yüksek tüketim düzeyine ulaşmalarıdır (Parasız, 2014:11). Tüketimi kısaca, "belirli bir ihtiyacımızı tatmin etmek için bir ürünü ya da hizmeti edinme, sahiplenme, kullanma ya da yok etme olarak tanımlamak olanaklıdır. Bu eylemi yapan birey ise tüketici olarak adlandırılabilir (Odabaşı, 1999:4). Tüketim tanımında vurgulanan en önemli unsur, ihtiyaçların tatminidir (Köroğlu, 2014:93). Tüketim, temelde bütün ekonomik faaliyetlerin nihai amacıdır. İnsanların yaşam düzeylerinin yükselmesinin en önemli göstergesi, daha yüksek tüketim düzeyine ulaşmalarıdır (Parasız, 2014:11).

Pazarlama yazınında tüketici, müşteri ve (satın) alıcı kavramları çoğunlukla birbirinin yerine kullanılıyor olsa da, bu üç kavram farklı anlamlara gelir. Tüketici; kişisel ya da ailesinin ihtiyaç, istek ve arzuları için pazarlama bileşenlerini satın alan ya da satın alma kapasitesinde olan gerçek bir kişidir. Tüketici; mal ve hizmetleri başka ürün ve hizmetlerin üretimi için değil de tamamen kişisel veya ailesel gereksinimleri için kullanan veya tüketen kişidir (Tek ve Özgül, 2013:113). Müşteri ise, bir işletmeden sürekli hizmet alan ya da devamlı aynı markayı satın alan tüketicidir. Dolayısıyla her müşteri tüketicidir ama her tüketici müşteri değildir. Firmalar açısından müşteri, süreklilik nedeniyle tüketici kavramına göre daha önemli bir kavram olarak ele alınmaktadır. Müşteri kavramı bir de örgütsel açıdan ele alınabilir. Üreticilerle tüketiciler arasında yer alan aracılar; yeniden üretim yapmak için mal ve hizmet satın alan işletmelerle hizmet işletmeleri örgütsel müşteri olarak adlandırılır. Alıcı, başkaları adına satın alma eylemini gerçekleştiren kişi ya da kurumlar olabilir. Satın alma eylemini gerçekleştiren kişi, söz konusu ürünün satın alınması ve kullanılmasına yönelik bir planlama ve zihinsel süreçten geçmemiş olabilir (İslamoğlu ve Altunışık, 2013:5-6).

Tüketici davranışları tüketicilerin ihtiyaç ve isteklerini tatmin etmek için, tüketim sürecinde yürüttükleri davranışların tümüdür (İslamoğlu ve Altunışık, 2013:8). Tüketici davranışı, bireylerin veya grupların ihtiyaç ve isteklerini karşılamak için, ürün ve hizmetleri seçme, satın alma, kullanma ve elden çıkarmadaki kararları ve bunlarla ilgili faaliyetleri içeren bir süreç olarak tanımlanabilir (Solomon, 1996:7).

Tüketici davranışının özellikleri 7 başlıkta ele alınabilir (Odabaşı ve Barış, 2010:30):

- Tüketici davranışı güdülenmiş bir davranıştır.

- Dinamik bir süreçtir. 
- Çeşitli faaliyetlerden oluşur.

- Karmaşıktır ve zamanlama açısından farklılıklar gösterir.

- Farklı rollerle ilgilenir.

- Farklı kişiler için farklılıklar gösterebilir.

- Çevre faktörlerinden etkilenir.

Tüketici davranışı; bireylerin ekonomik değeri olan ürün ve hizmetleri elde etme ve kullanmalarıyla doğrudan ilgili etkinlikler ve bu etkinliklere yol açan, belirleyen karar süreçleridir. Tüketici davranışı, sadece tüketimi değil, tüketiciyi ve hatta tüketicinin satın almaya ilişkin karar ve eylemlerini inceler. Bu bakımdan tüketici pazarlarını anlayabilmek ve değerlendirebilmek için tüketici davranışlarını etkileyen faktörlerin ve tüketici davranışlarının incelenmesi gerekir. $\mathrm{Bu}$ aynı zamanda tüketici yönlü modern pazarlama anlayışının bir gereğidir. Tüketici pazarları ve davranışları, karşılıklı bağımlı makro ve mikro pazarlama açılarından incelenebilir (Tek ve Özgül, 2013:114). Makro yaklaşım (sosyal bakış) toplum tarafından karşılanan tüketici sorunlarına çözüm aranması için gerekli olan yaklaşımdır. Kamu politikası uygulamaları, nüfus planlama çalışmaları, uyuşturucu ile mücadele gibi çalışmalar makro yaklaşım kapsamındadır. Mikro yaklaşımda ise tüketici davranışı daha çok firma başarısı üzerine kuruludur. Firmaların karlılıklarını arttırmaları ve başarılı olabilmeleri için tüketici davranışlarını incelemek muhakkak vazgeçilmez bir ön koşuldur (Odabaşı ve Barış, 2010:41). Tüketici davranışı, gerçekte tüketimi değil, tüketiciyi ve hatta tüketicinin satın almaya ilişkin karar ve eylemlerini inceler. $\mathrm{Bu}$ bakımdan tüketici pazarlarını anlayabilmek ve değerlendirebilmek için tüketici davranışlarını etkileyen faktörlerin ve davranışların incelenmesi gerekir (Yeşiloğlu, 2013:23).

Tüketici davranışını etkileyen birçok faktör olmakla beraber, bunları demografik, psikolojik ve sosyokültürel faktörler başlıkları altında sınıflandırmak mümkündür (Kotler, 2001: 144). Demografik faktörler; tüketicinin yaşı, aile durumu, meslek ve eğitim düzeyi, gelir düzeyi gibi unsurları içermektedir (Atılgan, 2003: 91). Psikolojik faktörler; tüketicilerin istekleri, güdüleri, algılaması, tutumu, kişiliği, öğrenme sürecidir. Ürünün nasıl algılandı̆̆ı, ürüne karşı gelişen tutumlar ve inançlar da o ürünün markası, kalitesi gibi unsurlar kadar tüketici satın alma davranışını etkilenmektedir. Psikolojik faktörler, ihtiyaç, motivasyon, öğrenme ve bellek, algılama, tutumlar ve inançlar olarak sayılabilir (Karafakığlu, 2006:94). Sosyokültürel faktörler; tüketicinin içerisinde yaşadığı çevreyle ilgili unsurlardan oluşmaktadır. Bunlar; aile, arkadaş çevresi, iş ortamı, toplumsal sınıflar ve kültürel faktörlerdir. Kültürel faktörler tüketici davranışlarında en derin ve en geniş etkiyi gösterirler (Kotler ve Armstrong, 1996:141). Tüketici davranışlarını etkileyen faktörler Tablo 1'de sunulmaktadır. 
Tablo 1: Tüketici Davranışlarını Etkileyen Faktörler

\begin{tabular}{|c|c|c|c|}
\hline Kültürel & Sosyal & Kişisel & Psikolojik \\
\hline Kültür & Referans (Danışma) Grupları & Yaş & Motivasyon \\
\hline Alt Kültür & Sosyal Ağlar & Meslek & Algılama \\
\hline Sosyal Sınıf & Aile & Ekonomik Durum & Öğrenme \\
\hline & Roller ve Statüler & Yaşam Tarzı & İnanç ve Tutum \\
\hline & & Kişilik ve Benlik & \\
\hline
\end{tabular}

Kaynak: Kotler ve Armstrong (2014), Principles of Marketing (Global Edition), 15E

Tüketici davranışını etkileyen faktörlerden biri de yaşam tarzıdır. Yaşam tarzı, bir kişinin psikografikleri olarak ifade edilen yaşam modelidir. Yaşam tarzı, tüketicilerin esas FIF (Faaliyet, İlgi Alanı, Fikir) boyutlarının ölçümünü içermektedir (Kotler and Armstrong, 2014: 169). Yaşam tarzı, insanların çevrelerinde nelere önem verdiklerini, dünya ve etrafındakiler hakkında neler düşündüklerini, zamanlarını nasıl geçirdiklerini belirleyen bir kavram olarak da bilinmektedir. Bu tanıma bağlı olarak yaşam tarzı, kişilerin aktivitelerinden, ilgilerinden ve düşüncelerinden oluşur. Kısaca (A-Activities I-Interests O-Opinions) AIOs olarak ifade edilir. Başka bir ifadeyle kişinin bazı davranışları (algısal tepkileri, yeme, içme, düşünsel becerileri) yaşam tarzına göre düzenlenir (Yeşiloğlu, 2013:3).

Yaşam tarzı, geniş anlamda, insanın boş zamanını nasıl geçirdiği (faaliyetleri), çevresinde nelere önem verdiği (ilgileri), dünya ve kendi hakkındaki düşünceleri (fikirleri) içeren bir yaşama biçimi olarak tanımlanabilir. Bir tüketici, pek çok mal ya da markayı, kendi yaşam tarzına uygun olduğu için satın alır ama bunun nedenini açıklayamaz (İslamoğlu ve Altunışık, 2013:167). Yaşam tarzı genel bir ifade ile "Biri nasıl yaşar?" sorusuna verilen cevaptır. İnsanların neler yaptıklarını, niçin yaptıklarını ve bunu yapmanın kendileri ve başkaları için ne anlama geldiğini anlatmaya yardımcı olur. Yaşam tarzı, değerleri ve zevkleri ortak olan tüketicilerin benzer tüketim modeli göstermesidir (Erciş, Ünal ve Can, 2007:284).

Bazı mal ve hizmetleri tüketiyor olmak bazı tüketiciler için diğerlerinden farklılaşmak anlamına gelmektedir. Buna göre kişileri yaşam tarzında gösterdikleri benzerliklere göre belirli kriterlere ayırmak mümkün olabilmektedir (Yeşiloğlu, 2013:5). Yaşam tarzı boyutları Tablo 2'de gösterilmektedir.

Yaşam tarzı analizi; bireylerin yaşamlarını nasıl sürdürdüklerine, tüketimle ilgili faaliyetlerine, ilgi alanlarına, alışkanlıklarına ve görüşlerine odaklanmaktadır (Foxall, Goldsmith ve Brown, 1998:148). Yaşama biçimi üzerinde güçlü etkisi olan demografik faktörlerle ilgili detayların toplanmasının yanında, kişilerin zamanlarını nasıl geçirdikleri, yaşamlarında yer alan farklı unsurların önem sırasının ne olduğu, kendileri ile ilgili ne hissettikleri sorularının cevapları aranmaktadır. Çünkü kişilerin yaşam tarzı tüketim 
davranışlarını veya başka bir deyişle, zaman, enerji ve paralarını nasıl harcayacaklarına dair verdikleri kararları etkiler. Bir tüketicinin gerçekte nasıl yaşadığının göstergesi olan yaşam tarzı aynı zamanda benlik kavramının yansımasıdır ve tüketicinin güdüleri - duyguları ve inançlarının içyüzünün anlaşılmasına yardımcı olmaktadır (Erdal, 2001:37).

Tablo 2: Yaşam Tarzı Boyutları

\begin{tabular}{|c|c|c|c|}
\hline Aktiviteler & İlgiler & Düşünceler & Demografikler \\
\hline İş & Aile & Kendisi & Yaş \\
\hline Hobiler & Ev & Sosyal Konular & Eğitim \\
\hline Sosyal Faaliyetler & İş & Politika & Gelir \\
\hline Tatiller & Toplum & İş Hayatı & Meslek \\
\hline Eğlenceler & Eğlence & Ekonomi & Aile Büyüklüğü \\
\hline Kulüp Üyelikleri & Moda & Eğitim & İkametgâh \\
\hline Çevre & Gıda & Ürün & Coğrafya \\
\hline Alışveriş & Medya & Gelecek & Şehir Büyüklüğü \\
\hline Spor & Amaçlar & Kültür & Yaşam Eğrisi \\
\hline
\end{tabular}

Kaynak: Solomon vd., (2006), Consumer Behaviour, p. 563

Yaşam tarzı ölçümleri tüketicilerin faaliyetlerini, ilgilerini, düşüncelerini, değerlerini, tutumlarını ve demografik özelliklerini temel alarak, tüketicilere bu temeller doğrultusunda sorular sorularak analiz edilmektedir. Bu özellikler ile tüketicinin yaşam tarzı arasında bir ilişki söz konusudur. Aynı zamanda tüketicinin yaşam tarzı ile davranışları arasında da bir ilişki vardır (Yeşiloğlu, 2013:9). Tüketicilerin, neden belirli ürünleri almaya eğilimli olduklarının araştırılmasında, yaşam tarzı analizleri yeni bir çıkış kapısı olmuştur. Bu şekilde mevcut ve potansiyel tüketicilerin beklenmeyen davranışları ortaya çıkarılabilmekte ve tüketiciye ait çok boyutlu portrelerin çizilmesine olanak verilmektedir. Tüketicilerin aktiviteleri, ilgi alanları ve görüşlerine ait bilginin dikkatle toplanması, davranış biçimlerinin tanımlanması bakımından son derece önemlidir. Demografik bilgiler ve yaşam tarzı analizi birlikte kullanılarak hedef tüketicilerin kimlerden oluştuğu çok daha kolay belirlenebilmektedir (Erdal, 2001:40).

Başlıca yaşam tarzı ölçümleri aşağıdaki gibi sıralanmaktadır (Y eşiloğlu, 2013:9):

- Değerler ve Yaşam Tarzı (VALS(Values and Life Styles)/VALS 2)

- Rokeach Değerler Ölçümü

- Değerler Listesi (LOV-List of Values)

- Prizm (Geo-Lifestyle) 
- FİF (Faaliyetler, İlgi Alanları, Fikirler)

Birçok güncel psikografik araştırma, tüketici gruplarını üç değişken kategorisinin bazı kombinasyonlarına göre oluşturmaya çalışmaktadır. Bu değişkenler FİF olarak bilinen Faaliyetler, İlgi Alanları, Fikirlerdir (Solomon vd., 2006, 563). Bu yöntemle, onun ilgileri, faaliyetleri ve düşünceleri ile yaşam tarzı ölçülür. Bu amaçla; tüketicinin faaliyetleri, ilgileri ve kanaatleri değişik sorularla ölçülmeye çalışılır. Bunun için önce faaliyetleri, ilgileri ve düşünceleri ölçmek için bir soru envanteri oluşturulur. Soru envanterinin amacı, bireyi bu üç boyut bakımından ölçmek ve bireyin yaşam tarzı hakkında fikir edinmektir (İslamoğlu ve Altunışık, 2013:169). FİF (AIO) ölçeğinde 56 tutum ifadesi bulunmaktadır. FİF (AIO), tüketicilere aktivitelerini (spor, eğlence, hobi, alışveriş vb.), ilgi alanlarını (yemek, moda, ev vb.) ve fikirlerini (kendileri, sos-yal kavramlar, ürünler vb. hakkında) sorarak tüketicilerin kişilik özelliklerini açıklamaya çalışmaktadır (Eryiğit ve Kavak, 2008:29). FIF ifadelerinde amaç, tüketicilerin yaşam tarzlarını tespit etmek ve tüketicilerin ilgileri ve fikirlerini belirleyerek kişiliklerini tahmine çalışmaktır. Faaliyet konusu tüketicilerin ne yaptıkları, ne aldıkları ve boş zamanlarını nasıl değerlendirdiklerine ilişkin sorulardan oluşmaktadır. İlgi alanı, tüketici tercihleri ve öncelikleri hakkındaki sorulardan, fikirler ise tüketicilerin dünya, yerel, moral, ekonomik ve sosyal ilişkiler hakkındaki görüş ve duygularını ortaya çıkarmaya yarayan sorulardan oluşur (Erciş, Ünal ve Can, 2007:285). FİF ölçeğinde kullanılan ifadelerin Türkiye'de yaşayan tüketici profilinin yaşam tarzını ölçmek için daha uygun olabileceği düşüncesiyle, bu araştırmada yaşam tarzı ölçümünde kullanılabilecek 5 farklı ölçüm arasından FİF ölçeği seçilmiştir.

\section{Romanların Tüketim Eksenli Yaşam Tarzlarının İncelenmesi İle İlgili Bir Uygulama}

\subsection{Araştırmanın Konusu}

Araştırma, Roman vatandaşların tüketim açısından yaşam tarzı kalıplarının belirlenmesini konu edinmektedir. Bursa ilinde yaşayan Roman topluluklar, araştırmanın konusuna dâhil edilmiştir.

\subsection{Araştırmanın Önemi Ve Amacı}

Tüketici davranışını etkileyen kişisel faktörlerden biri olan yaşam tarzı, tüketimi kişisel yaşam tercihlerine bağlı olarak açıklamaya çalışmaktadır. Tüketiciler, yaşam tarzları bakımından farklı tüketim davranışları sergilemektedir. Bir tüketici topluluğunun yaşam tarzlarının belirlenmesi, o topluluğun tüketim davranışlarını anlama konusunda yardımcı olacaktır. Roman tüketicilerin yaşam tarzlarının incelenmesi, Romanların tüketim şekillerini belirleme konusunda önemli ipuçları sağlayacaktır. Bu çalışma, Romanların yaşam tarzlarını Faaliyet, İlgi Alanı ve Fikirler (FİF-AIO) bakımından ölçmeyi amaçlamaktadır. Çalışmada ayrıca cinsiyetlerine göre gruplandırılabilecek Roman tüketicilerin yaşam tarzlarının 
farklılaşıp farklılaşmadığı sınanmaktır. Araştırma, Bursa özelinde Romanların tüketim eksenli yaşam tarzlarının belirlenerek, Roman tüketicilere ve firma yöneticilerine yol göstermesi açısından önem taşımaktadır. Ayrıca yapılan literatür taraması sonucunda Romanların satın alma davranışlarının incelenmesi konusunda çalışmalar bulunmakla birlikte, Romanların tüketim açısından yaşam tarzlarının incelenmesiyle ilgili bir çalışmaya rastlanmamıştır. $\mathrm{Bu}$ çalışma bu yönüyle de önem taşımaktadır.

\subsection{Araştırmanın Yöntemi}

$\mathrm{Bu}$ çalışma uygulamalı bir araştırmadır. Tasarımı ise tanımlayıcı (betimsel) araştırma olarak ifade edilebilir. Araştırmanın problemi, Roman vatandaşların yaşam tarzlarını tüketim davranışları dikkate alınarak incelemektir.

Araştırmada veriler anket yöntemiyle elde edilmiştir. Araştırma, Bursa şehir merkezinde yaşayan Roman vatandaşlara yönelik gerçekleştirilmiştir. Araştırmanın ana kütlesi Bursa şehir merkezinde yaşayan tüm Romanlardır. Bu ana kütle içerisinden kolayda örnekleme yoluyla ulaşılabilen ve ankete katılmayı kabul eden Romanlar araştırmanın örneklemini oluşturmaktadır. Araştırmada kullanılan anketler Ekim 2015 ayı içerisinde uygulanmıştır. Anketler yüz yüze anket uygulaması şeklinde gerçekleştirilmiştir. Anket formunda ilk olarak demografik özelliklerin ölçüldüğü soru grubu yer almaktadır. Daha sonra katılımcıların tüketim davranışlarını incelemek amacıyla farklı tüketim konularını içeren sorular sorulmuştur. Tüketim sorularından sonra katılımcılara yaşamlarını sürdürdükleri Bursa şehri ile ilgili düşüncelerini içeren sorular ve kendilerini ifade ettikleri "Roman" sözcüğü ile ilgili algıları sorulmaktadır. Anketin son bölümünde ise daha önce belirtilen ve yaşam tarzı ölçümünde sıklıkla kullanılan FİF ölçeği ile katılımcıların yaşam tarzları ölçülmeye çalışılmıştır. Fİ ölçeği yine daha önce belirtildiği üzere 56 ifadeden oluşan bir ölçektir. Anket yoluyla elde edilen FİF ölçeği cevapları Güvenilirlik Analizine tabi tutulmuştur. Analiz sonuçlarına göre 56 ifade için Cronbach'ın Alfa Katsayısı 0,818 çıkmıştır. $\mathrm{Bu}$ sonuç, FİF yaşam tarzı ölçeği ile yapılan ölçümün güvenilirliğinin yüksek düzeyde olduğunu göstermektedir. Anket uygulaması sonucunda 190 adet kullanılabilir anket formundan elde edilen verilere Yüzde Analizi, Mertebeli Dereceleme, Faktör Analizi ve Varyans Analizi uygulanmıştır.

\subsection{Araştırmanın Bulguları}

\subsubsection{Katılımcıların Demografik ve Tüketim Bilgileri}

Araştırmaya katılan Roman tüketicilerin demografik bilgilerine bakıldığında, yaş dağılımının genellikle 26-40 yaş aralığında ve yaş ortalamasının ise 33,38 olduğu söylenebilir. Erkeklerin kadınlara göre daha fazla $(\% 62,1)$ olduğu ve yine evlilerin bekârlara göre daha fazla (\%72) olduğu görülmektedir. Cevaplayıcılar gelir düzeyleri bakımından 
incelendiğinde ise katılımcıların yaklaşık \%57'sinin gelirinin 1.001 TL ile 2.000 TL arasında olduğu görülmektedir. Gelir sorusuna cevap veren 123 katılımcının gelir ortalaması ise yaklaşık 1.370 TL olarak hesaplanmıştır. Değerler Tablo 3'te gösterilmektedir.

Tablo 3: Katılımcıların Demografik Bilgileri-1

\begin{tabular}{|c|c|c|c|c|c|}
\hline$\underline{\text { YASS }}$ & $\underline{\mathbf{F}}$ & $\underline{\%}$ & CINSIYET & $\underline{\mathbf{F}}$ & $\underline{\%}$ \\
\hline 25 yaş ve altı & 50 & 26,6 & Erkek & 118 & 62,1 \\
\hline $26-40$ yaş arası & 94 & 50 & Kadın & 72 & 37,9 \\
\hline 41 yaş ve üzeri & 44 & 23,4 & TOPLAM & 190 & 100 \\
\hline \multirow[t]{2}{*}{ TOPLAM } & 188 & 100 & & & \\
\hline & & & $\underline{\text { GELIR (TL) }}$ & $\underline{F}$ & $\underline{\%}$ \\
\hline$\underline{\text { MEDENİ HAL }}$ & $\underline{F}$ & $\underline{\%}$ & 1.000 ve alt 1 & 43 & 35 \\
\hline Evli & 134 & 72 & $1.001-2.000$ aras 1 & 70 & 56,9 \\
\hline Bekâr & 52 & 28 & 2.001 ve üstü & 10 & 8,1 \\
\hline TOPLAM & 186 & 100 & TOPLAM & 123 & 100 \\
\hline
\end{tabular}

Tablo 4'te araştırmaya katılan Roman tüketicilerin eğitim ve meslek bilgileri sunulmuştur. Tablodaki bilgilere göre katılımcıların eğitim düzeyleri ilköğretim $(\% 60,9)$ ve ortaöğretim $(\% 33,7)$ olarak belirlenmiştir. Katılımcıların büyük çoğunluğunun eğitim düzeyinin üniversite öncesi olduğu görülmektedir. Katılımcılara meslekleri sorulduğunda serbest meslek \%32,5 oranla ilk sırada gelmektedir. Katılımcıların \%11,8'i meslek olarak müzisyenliği bildirmişlerdir.

Tablo 4: Katılımcıların Demografik Bilgileri-2

\begin{tabular}{|c|c|c|c|c|c|}
\hline EĞITİM & $\underline{\mathbf{F}}$ & $\underline{\%}$ & MESLEK & $\underline{\mathbf{F}}$ & $\underline{\%}$ \\
\hline İlköğretim & 112 & 60,9 & Öğrenci & 10 & 5,9 \\
\hline Ortaöğretim & 62 & 33,7 & Serbest Meslek & 55 & 32,5 \\
\hline Ön lisans & 5 & 2,7 & Müzisyen & 20 & 11,8 \\
\hline Lisans & 5 & 2,7 & Ev Hanımı & 27 & 16,0 \\
\hline \multirow[t]{4}{*}{ TOPLAM } & 184 & 100 & Emekli & 9 & 5,3 \\
\hline & & & İşçi & 19 & 11,2 \\
\hline & & & Diğer & 29 & 17,2 \\
\hline & & & TOPLAM & 169 & 100 \\
\hline
\end{tabular}

Araştırmaya katılanlara bazı tüketim davranışları ve tercihleri sorulmuştur. Bunlardan ilki kullandıkları akıllı telefon markasıdır. Verilen cevaplar Tablo 5'te gösterilmektedir. Araştırmaya katılanlardan 123 katılımcı, kullandığı akıllı telefon markasını belirtmiştir. En çok kullanılan akıllı telefon markası Samsung olarak ortaya çıkmaktadır. İkinci sırada ise Nokia gelmektedir. 
Tablo 5: Kat1lımciların Akıllı Telefon Tercihleri

\begin{tabular}{ccc}
\hline Kullanılan Akıllı TLF & $\underline{\mathbf{F}}$ & $\underline{\underline{\mathbf{\%}}}$ \\
\hline Samsung & 59 & 48,0 \\
Nokia & 27 & 22,0 \\
Iphone & 12 & 9,8 \\
General Mobile & 5 & 4,1 \\
Diğer & 20 & 16,1 \\
Toplam & $\mathbf{1 2 3}$ & $\mathbf{1 0 0}$ \\
\hline
\end{tabular}

Araştırmaya katılan Roman tüketicilere kredi kartı kullanıp kullanmadıkları ve kullanıyorlarsa kaç adet kartları olduğu sorulmuştur. Tablo 6' da verilen bilgilere göre katılımcıların hemen hemen yarısı \%53 kredi kartı kullandıklarını, kullananların da çoğunluğu $(\% 60,7)$ tek kart kullandıklarını belirtmişlerdir.

Tablo 6: Katılımcıların Kredi Kartı Kullanım Bilgileri

\begin{tabular}{|c|c|c|c|c|c|}
\hline$\underline{\text { Kredi Kartı }}$ & $\underline{\mathbf{F}}$ & $\underline{\%}$ & $\underline{\text { Kredi Kartı Adet }}$ & $\underline{\mathbf{F}}$ & $\underline{\%}$ \\
\hline Var & 94 & 53,1 & 1 & 37 & 60,7 \\
\hline Yok & 83 & 46,9 & 2 & 12 & 19,7 \\
\hline \multirow[t]{4}{*}{ TOPLAM } & 177 & 100 & 3 & 7 & 11,5 \\
\hline & & & 4 & 4 & 6,6 \\
\hline & & & 5 & 1 & 1,6 \\
\hline & & & TOPLAM & 61 & 100 \\
\hline
\end{tabular}

Katılımcıların TV izleme tercihlerine verdikleri cevaplar, aşağıdaki tabloda özetlenmektedir. Araştırmaya katılan Romanların günde ortalama olarak yaklaşık 4,5 saat TV izledikleri anlaşılmaktadır. Ayrıca katılımcılardan en çok izledikleri TV kanallarını izleme sırasına göre sıralamaları istenmiş ve cevaplar mertebeli dereceleme yöntemine göre hesaplanmıştır. Sıralı bir ölçek olan mertebeli derecelemede nesneler, cevaplayıcıya tesadüfi (ya da alfabetik) bir sırada sunulur ve belirli bir ölçüte göre sıralanması istenir. Burada ikili karşılaştırma olmayıp, önem derecesine göre sıralama söz konusudur (Nakip, 2006:138). Araştırmaya katılanların, TV kanalı bakımından Star TV, ATV ve Kanal D’yi çoğunlukla tercih ettikleri anlaşılmaktadır.

Tablo 7: Katılımcıların TV İzleme Tercihleri

\begin{tabular}{|c|c|c|c|c|}
\hline$\frac{\text { Günlük TV }}{\text { Izleme (saat) }}$ & $\underline{\mathbf{F}}$ & \% & $\frac{\text { En Cok Izlenen }}{\text { TV Kanalları }}$ & Puan* \\
\hline 1 & 8 & 4,4 & Star Tv & 246 \\
\hline 2 & 25 & 13,7 & Atv & 180 \\
\hline 3 & 39 & 21,4 & Kanal D & 149 \\
\hline 4 & 30 & 16,5 & Trt1 & 116 \\
\hline 5 & 25 & 13,7 & Show tv & 114 \\
\hline 6 & 22 & 12,1 & Fox tv & 84 \\
\hline 7 ve üzeri & 33 & 18,1 & Kanal 7 & 40 \\
\hline Toplam & 182 & 100 & Olay Tv & 17 \\
\hline
\end{tabular}

Araştırmaya katılan ve Bursa'da yaşayan Roman vatandaşların Bursa şehri ile ilgili değerlendirmeleri, açık uçlu olarak sorulmuştur. Verilen cevaplar Tablo 8'de sıralanmıştır. 
Araştırmaya katılanlara göre Bursa'nın en çok sevilen yanının doğası ve tarihi olduğu ifade edilmiştir. Hiç sevilmeyen özellikleri ise trafiği ve ayrımcılığı olarak belirtilmiştir. Bursa şehri doğal güzellikleri ve tarihi geçmişi ile Türkiye'nin önemli şehirlerinden birisidir (http://www.bursa.com.tr/, Erişim Tarihi: 22.10.2016). Son yıllarda artan nüfus oranı ve taşıt sayısı nedeniyle Bursa şehir merkezinde trafik yoğunluğunun daha fazla yaşandığ söylenebilir (http://www.yenidonem.com.tr/yazar/n-nuri-yavuz/bursa\%E2\%80\%99da-trafikve-yonetimi/1755.html, Erişim Tarihi: 15.02.2016). Bursa'da sevilmeyen ikinci özellik ise ayrımcılık olarak belirtilmiştir. Romanların toplumsal olarak muzdarip oldukları konuların başında onlara karşı uygulanan ayrımcılık gelmektedir. Bu sosyolojik konu ile ilgili literatürde birçok çalışma bulunmaktadır. Ayrıca Roman vatandaşlar, tüketim davranışı ile ilgili olarak alışveriş sırasında mağaza personelinden ayrımcılıktan uzak bir tavır ve herhangi bir müşteri gibi kendileri ile de aynı şekilde ilgilenilmesini beklemektedirler (Özsoy, 2014:87).

Tablo 8: Araştırmaya Katılanların Bursa Şehri İle İlgili Düşünceleri

\begin{tabular}{|c|c|c|c|}
\hline$\frac{\text { Bursa'nın Sevilen } 3}{\underline{\text { Özelliği }}}$ & Puan* & $\frac{\text { Bursa'nın Sevilmeyen } 3}{\underline{\text { Özelliği }}}$ & Puan** \\
\hline Doğa & 507 & Trafik & 242 \\
\hline Tarihi & 311 & Ayrımcılık & 222 \\
\hline İnsanlar & 51 & Çevre Kirliliği & 170 \\
\hline
\end{tabular}

* Araştırmaya katılanlardan Bursa'nın sevdikleri 3 yönünü en çok sevdiklerinden başlayarak sıralamaları istenmiş ve cevaplar mertebeli dereceleme yöntemiyle puanlamaya tabi tutulmuştur.

** Araştırmaya katılanlardan Bursa'nın sevmedikleri 3 yönünü hiç sevmediklerinden başlayarak sıralamaları istenmiş ve cevaplar mertebeli dereceleme yöntemiyle puanlamaya tabi tutulmuştur.

Araştırmaya katılan Roman vatandaşlara Bursa'da yaşamaktan duydukları memnuniyet düzeyi sorulduğunda, yaklaşık \%85'i memnun olduklarını belirtmişlerdir. Bursa medeniyet, kültür ve tarih şehri olarak farklı dil, din, ırk veya mezhepten insanların bir arada huzur içerisinde yaşadıkları bir yaşam sunmaktadır.

Tablo 9: Araştırmaya Katılanların Bursa'da Yaşamaktan Duydukları Memnuniyet Düzeyleri

\begin{tabular}{ccc}
\hline & $\underline{\mathbf{F}}$ & $\underline{\mathbf{\%}}$ \\
\hline Hiç Memnun Değilim & 5 & 2,7 \\
Memnun Değilim & 6 & 3,2 \\
Fikrim Yok & 19 & 10,2 \\
Memnunum & 105 & 56,1 \\
Çok Memnunum & 52 & 27,8 \\
Toplam & $\mathbf{1 8 7}$ & $\mathbf{1 0 0}$ \\
\hline
\end{tabular}

Katılımcılara "Roman” sözcüğünün kendilerine neyi hatırlattığı sorulmuştur. Bu soruda yönlendirme yapmamak için seçenek verilmemiş, soru açık uçlu olarak sorulmuştur. Verilen cevaplar mertebeli dereceleme yöntemiyle sıralanmıştır. Sonuç, Tablo 10'da sunulmaktadır. Romanların aklına "Roman” sözcüğü, "eğlence” ve "renkli” kavramlarını getirmektedir. 
Tablo 10: Araştırmaya Katılanlara Roman Sözcüğünün Çağrıştırdıkları

\begin{tabular}{cc}
\hline Roman Deyince Akla Gelenler & $\underline{\text { Puan }}^{*}$ \\
\hline Eğlence & 393 \\
\hline Renkli & 301 \\
Fakirlik & 99 \\
Cahillik & 78 \\
Milliyetçi & 83 \\
\hline
\end{tabular}

* Araştırmaya katılanlardan Roman deyince akıllarına gelen 3 şeyi ilk aklına gelenden başlayarak sıralamaları istenmiş ve cevaplar mertebeli dereceleme yöntemiyle puanlamaya tabi tutulmuştur.

\subsubsection{Araştırmaya Katılanların Yaşam Tarzı İfadelerine Katılma Düzeyleri}

Araştırmaya katılanlara FİF Yaşam Tarzı Ölçeğinde yer alan 56 ifade 5'li Likert tipi dereceleme ile sorulmuştur. Yaşam tarzı ifadelerine Roman katılımcıların verdikleri cevaplar ve katılım düzeyleri Tablo 11'de gösterilmektedir.

Tablo 11: Araştırmaya Katılanların Yaşam Tarzı İfadelerine Katılma Düzeyleri

\begin{tabular}{|c|c|c|c|}
\hline İFADELER & $\mathrm{N}$ & Ort. & $\begin{array}{c}\text { Standart } \\
\text { Sapma }\end{array}$ \\
\hline En basit bir ürün için bile fiyat kontrolü yaparım. & 167 & 3,80 & 1,214 \\
\hline Şık giyinmek benim hayatımın önemli bir parçasıdır. & 166 & 3,54 & 1,315 \\
\hline Düzenli olarak hastane ya da benzeri yerlerde gönüllü toplum hizmetinde bulunmaktayım. & 166 & 2,59 & 1,289 \\
\hline Kredi kartı sahibi olmak iyidir. & 165 & 2,40 & 1,258 \\
\hline Reklamları genellikle indirimlerden haberdar olmak için izlerim. & 168 & 2,86 & 1,301 \\
\hline Birden fazla sivil toplum kuruluşunda aktif olarak çalışmaktayım. & 166 & 2,39 & 1,278 \\
\hline Evimi temiz ve düzenli tutarım. & 168 & 4,18 & 1,076 \\
\hline Düzenli olarak spor yaparım. & 165 & 3,05 & 1,317 \\
\hline Çoğu insandan daha fazla özgüvene sahibim. & 164 & 3,63 & 1,120 \\
\hline Dansa gitmektense sportif faaliyetlere katılmayı tercih ederim. & 168 & 3,40 & 1,305 \\
\hline Konserve yiyecek olmadan yapamam. & 164 & 2,02 & 1,124 \\
\hline Dünya turuna çıkmayı isterim. & 166 & 3,82 & 1,285 \\
\hline Aldığım her şey için peşin ödeme yapmayı severim. & 167 & 4,12 & 1,155 \\
\hline Arkadaşlarımın ne alacaklarını bazen etkiliyorum. & 165 & 3,05 & 1,331 \\
\hline Çocuklarım hastalanınca sadece onları rahat ettirmeyi düşünürüm. & 154 & 3,93 & 1,363 \\
\hline Muhtemelen önümüzdeki yıl harcayacak daha fazla param olacak. & 162 & 3,08 & 1,360 \\
\hline Her türlü ev işini severim. & 158 & 3,27 & 1,366 \\
\hline Sıcak havalarda genellikle düşük kalorili alkolsüz içecekleri tercih ederim. & 161 & 3,41 & 1,371 \\
\hline Özel ihtiyaçlarım için alışverişe çıkarım. & 161 & 4,12 & 1,126 \\
\hline Futbol ya da basketbol maçlarını izlemeyi veya dinlemeyi severim. & 162 & 3,20 & 1,537 \\
\hline Bir terzi gibi dikiş dikmek isterim. & 161 & 2,89 & 1,414 \\
\hline Başkalarının beni lider olarak görmesi hoşuma gider. & 162 & 3,33 & 1,314 \\
\hline Bundan beş yıl sonra evimize giren para muhtemelen bugünkünden çok daha fazla olacak. & 160 & 3,44 & 1,321 \\
\hline Evin temizliğini üstünkörü yaparım. & 157 & 2,15 & 1,300 \\
\hline Konserve gıdaların tadı bana güzel gelmiyor. & 159 & 3,31 & 1,432 \\
\hline Arkadaşlarımla markalar ve ürünler hakkında çok muhabbet ederiz. & 159 & 3,09 & 1,418 \\
\hline Yabancı bir ülkede bir yıl yaşamak isterim. & 161 & 3,70 & 1,328 \\
\hline
\end{tabular}




\begin{tabular}{|c|c|c|c|}
\hline Çocuklarım yaşamımdaki en önemli varlıklardır. & 149 & 4,30 & 1,184 \\
\hline Çocuklarımın ve benim giysilerimi genellikle ben dikerim. & 152 & 2,26 & 1,289 \\
\hline Günde en az bir öğün konserve yiyecek kullanırım. & 158 & 1,89 & 1,059 \\
\hline Ben bir ev kuşuyum. & 158 & 2,54 & 1,444 \\
\hline Alışverişte pazarlık yapılarak çok fazla para tasarruf edilebilir. & 161 & 4,09 & 1,100 \\
\hline Çoğu insandan daha bağımsızım. & 159 & 3,55 & 1,205 \\
\hline İtiraf etmeliyim ki, ev/oda temizlemeyi fazla sevmem. & 158 & 2,66 & 1,466 \\
\hline Yoğun müzik ve sohbetli eğlence toplantılarını severim. & 161 & 3,53 & 1,432 \\
\hline Dans etmektense spor yapmayı tercih ederim. & 162 & 3,54 & 1,276 \\
\hline Evi çocukların rahat edeceği şekilde düzenlerim. & 148 & 3,96 & 1,142 \\
\hline $\begin{array}{l}\text { Eğer iki kıyafet arasından birisini seçmem gerekiyorsa rahat olanın yerine modaya uygun } \\
\text { olanını tercih ederim. }\end{array}$ & 161 & 2,93 & 1,443 \\
\hline Bir marka hakkında bilgi almak için insanlar, benim onlara gittiğimden daha fazla, bana gelirler. & 158 & 2,78 & 1,270 \\
\hline En son saç stillerini sıklıkla kendi saçımda denerim. & 157 & 2,79 & 1,340 \\
\hline Genellikle daha fazla düşük kalorili diyet ürünü yiyecek alırım. & 159 & 2,71 & 1,275 \\
\hline Evde sessiz oturacağıma dışarıda bir eğlenceye giderim. & 158 & 3,19 & 1,378 \\
\hline Benim için ev/oda temizleme zevksiz bir iştir. & 157 & 2,55 & 1,434 \\
\hline Pek çok yeteneğim var. & 160 & 3,56 & 1,109 \\
\hline Çocukların iyi alışkanlıklar ve huylar kazanmaları için çok çaba ve zaman harcarım. & 147 & 3,94 & 1,278 \\
\hline Dikiş dikmeyi severim ve çok sık dikiş dikerim. & 157 & 2,44 & 1,268 \\
\hline Arkadaşlarım ve komşularım sık sık bana akıl danışmaya gelir. & 159 & 3,05 & 1,272 \\
\hline Evim tamamen temiz değilse rahat edemem. & 159 & 4,07 & 1,026 \\
\hline Çocukların oyuncaklarını evin her yerine dağıtmasını sevmiyorum. & 146 & 3,85 & 1,234 \\
\hline Yeni mağazalara arkadaşlarım ve komşularımdan önce giderim. & 157 & 2,60 & 1,245 \\
\hline Toplum yararına olan projelerde çalışmayı severim. & 158 & 3,75 & 1,111 \\
\hline İnsanlar kendi kıyafetlerini dikerek çok fazla para tasarruf edebilirler. & 158 & 3,48 & 1,310 \\
\hline Politik (siyasi) kampanyalarda bizzat görev aldım. & 155 & 2,50 & 1,306 \\
\hline Son moda kiyafetlerden en az bir kat alırım. & 155 & 2,77 & 1,341 \\
\hline Hangi marka alsam diye sık sık arkadaşlarıma danışırım. & 156 & 2,49 & 1,332 \\
\hline Günde en az bir öğün diyet yiyeceği yemeliyim. & 155 & 2,35 & 1,403 \\
\hline
\end{tabular}

* 1: Hiç Katılmıyorum, 2: Katılmıyorum, 3: Kararsızım, 4: Katılıyorum, 5: Tamamen Katılıyorum

İfadelere katılma düzeylerinin ortalama değerlerine bakıldığında en yüksek katılım düzeyi olan ifadeler aşağıdaki tabloda gösterilmektedir.

\begin{tabular}{c|cc}
\hline Sıra No & PUANI EN YÜKSEK IFADELER & $\underline{\text { PUAN* }}^{*}$ \\
\hline 1 & Çocuklarım yaşamımdaki en önemli varlıklardır. & 4,30 \\
\hline 2 & Evimi temiz ve düzenli tutarım. & 4,18 \\
\hline 4 & Aldığım her şey için peşin ödeme yapmayı severim. & 4,12 \\
\hline 5 & Özel ihtiyaçlarım için alışverişe çıkarım. & 4,12 \\
\hline 6 & Dünya turuna çıkmayı isterim. & 4,11 \\
\hline 7 & Alışverişte pazarlık yapılarak çok fazla para tasarruf edilebilir. & 4,09 \\
\hline 8 & Evim tamamen temiz değilse rahat edemem. & 4,09 \\
\hline
\end{tabular}


Tabloya göre Roman katılımcılar, en çok çocuklarını önemsemekte ve ev temizliğine önem vermektedir. Harcamalarına da dikkat ettikleri ifade edilebilir.

Katılım düzeyi en düşük ifadelere bakıldığında ise aşağıdaki tablo ortaya çıkmaktadır.

\begin{tabular}{c|cc}
\hline Sıra No & PUANI EN DÜSÜK IFADELER & $\underline{\text { PUAN* }}$ \\
\hline 1 & Politik (siyasi) kampanyalarda bizzat görev aldım. & 2,50 \\
\hline 2 & Hangi marka alsam diye sık sık arkadaşlarıma danışırım. & 2,49 \\
3 & Kredi kartı sahibi olmak iyidir. & 2,47 \\
\hline 4 & Dikiş dikmeyi severim ve çok sık dikiş dikerim. & 2,44 \\
\hline 5 & Birden fazla sivil toplum kuruluşunda aktif olarak çalışmaktayım. & 2,39 \\
\hline 6 & Günde en az bir öğün diyet yiyeceği yemeliyim. & 2,35 \\
\hline 8 & Evin temizliğini üstünkörü yaparım. & 2,15 \\
\hline 9 & Konserve yiyecek olmadan yapamam. & 2,02 \\
\hline
\end{tabular}

Tablodaki verilere göre, araştırmaya katılan Romanların STK ve politik kampanyalarda aktif görev almaktan uzak durduğu, kredi kartı kullanmak istemediği ve hazır gıdalardan da uzak durduğu anlaşılmaktadır.

\subsubsection{FİF Yaşam Tarzı Ölçeğinin Faktöriyel Dağılımı}

FİF Yaşam Tarzı Ölçeği 56 ifadeden oluşmaktadır. Araştırmada 190 anket kullanılabilir bulunmuştur. Faktör analizi yapılabilmesi için gözlem sayısının değişken sayısından en az dört veya beş kat fazla olması gerekmektedir (Malhotra ve Birks, 206, 575). $\mathrm{Bu}$ nedenle araştırma kapsamında Faktör Analizi uygulanamamaktadır. Literatür taraması sonucu FİF ölçeği kullanılan bazı çalışmalarda (Küçükemiroğlu, 1999; Kavak ve Gümüşlüoğlu, 2007) bu 56 ifadenin belirli faktörler altında toplandığı belirtilmektedir. Roman tüketicilere yönelik uygulanan bu araştırmada, literatür taraması sonucu ulaşılan çalışmalardan yola çıkılarak 56 ifadeli FİF Ölçeği, 13 faktör altında gösterilmiştir. İfadelerin faktöriyel gösterimleri Tablo 12'de görülmektedir.

Tablo 12: FİF Yaşam Tarzı Ölçeğinin Faktöriyel Gösterimi

\begin{tabular}{cc}
\hline$\underline{\text { FAKTÖR }}$ & $\underline{\text { YAŞAM TARZI IFADELERİ }}$ \\
\hline Faktör 1: & Reklamları genellikle indirimlerden haberdar olmak için izlerim. \\
\hline Aile Odaklılık & Çocuklarım hastalanınca sadece onları rahat ettirmeyi düşünürüm. \\
\hline & Muhtemelen önümüzdeki yıl harcayacak daha fazla param olacak. \\
\hline & Çocuklarım yaşamımdaki en önemli varlıklardır. \\
\hline
\end{tabular}


Çocukların iyi alışkanlıklar ve huylar kazanmaları için çok çaba ve zaman harcarım.

Şık giyinmek benim hayatımın önemli bir parçasıdır.

Arkadaşlarımla markalar ve ürünler hakkında çok muhabbet ederiz.

Faktör 2:

Eğer iki kıyafet arasından birisini seçmem gerekiyorsa rahat olanın yerine modaya uygun olanını tercih ederim.

En son saç stillerini sıklıkla kendi saçımda denerim.

Modaya Düsskünlük

Yeni mağazalara arkadaşlarım ve komşularımdan önce giderim.

Son moda kiyafetlerden en az bir kat alırım.

Hangi marka alsam diye sık sık arkadaşlarıma danışırım.

Faktör 4:

$\underline{\text { Liderlik }}$

\section{Sağlığa Düsskünlük \\ Sağlığa Düsskünlük}

Sıcak havalarda genellikle düşük kalorili alkolsüz içecekleri tercih ederim.

Genellikle daha fazla düşük kalorili diyet ürünü yiyecek alırım.

Günde en az bir öğün diyet yiyeceği yemeliyim.

Çoğu insandan daha fazla özgüvene sahibim.

Arkadaşlarımın ne alacaklarını bazen etkiliyorum.

Başkalarının beni lider olarak görmesi hoşuma gider.

Çoğu insandan daha bağımsızım.

Bir marka hakkında bilgi almak için insanlar, benim onlara gittiğimden daha fazla, bana gelirler.

Pek çok yeteneğim var.

Arkadaşlarım ve komşularım sık sık bana akıl danışmaya gelir.

Evimi temiz ve düzenli tutarım.

Faktör 5:

Dansa gitmektense sportif faaliyetlere katılmayı tercih ederim.

Her türlü ev işini severim.

Bakım

Evim tamamen temiz değilse rahat edemem.

Çocukların oyuncaklarını evin her yerine dağıtmasını sevmiyorum.

Faktör 6:

Aldığım her şey için peşin ödeme yapmayı severim.

$\underline{\text { Kaygısızlık }}$

Evin temizliğini üstünkörü yaparım.

İtiraf etmeliyim ki, ev/oda temizlemeyi fazla sevmem.

Benim için ev/oda temizleme zevksiz bir iştir.

Kredi kartı sahibi olmak iyidir.

Faktör 7:

Konserve yiyecek olmadan yapamam.

Pratiklik

Günde en az bir öğün konserve yiyecek kullanırım.

Konserve gıdaların tadı bana güzel gelmiyor. (Ters Kayıt)

Faktör 8:

$\underline{\text { Zanaatkârlık }}$

Bir terzi gibi dikiş dikmek isterim.

Çocuklarımın ve benim giysilerimi genellikle ben dikerim.

Dikiş dikmeyi severim ve çok sık dikiş dikerim.

Faktör 9:

Toplum Bilinci

Faktör 10:

$\underline{\text { Maliyet Bilinci }}$

Düzenli olarak hastane ya da benzeri yerlerde gönüllü toplum hizmetinde bulunmaktayım.

Faktör 11:

Birden fazla sivil toplum kuruluşunda aktif olarak çalışmaktayım.

Toplum yararına olan projelerde çalışmayı severim.

Politik (siyasi) kampanyalarda bizzat görev aldım.

En basit bir ürün için bile fiyat kontrolü yaparım.

Alışverişte pazarlık yapılarak çok fazla para tasarruf edilebilir.

İnsanlar kendi kıyafetlerini dikerek çok fazla para tasarruf edebilirler.

Özel ihtiyaçlarım için alışverişe çıkarım. (Ters Kayıt)

Ben bir ev kuşuyum. (Ters Kayıt) 


\begin{tabular}{cc}
\hline$\underline{\text { Dıșadönüklük }}$ & Yoğun müzik ve sohbetli eğlence toplantılarını severim. \\
\hline $\begin{array}{c}\text { Faktör 12: } \\
\text { Evde sessiz oturacağıma dışarıda bir eğlenceye giderim. }\end{array}$ \\
\hline$\underline{\text { Faktör 13: }}$ & Dünya turuna çıkmayı isterim. \\
\hline$\underline{\text { Spora İlgi }}$ & Yabancı bir ülkede bir yıl yaşamak isterim. \\
\hline
\end{tabular}

Araştırmaya katılan Roman tüketicilerin 56 ifadelik yaşam tarzı ölçeğine verdikleri cevapların yukarıda bahsedilen 13 faktör bakımından ortalama değerleri ve standart sapmaları Tablo 13'te gösterilmektedir.

Tablo 13: Yaşam Tarzı Ölçeğinin Faktörler Bakımından Ortalama Değerleri

\begin{tabular}{|c|c|c|c|}
\hline & $\underline{\mathbf{N}}$ & $\underline{\text { Ort. }^{1}}$ & $\frac{\text { Standart }}{\underline{\text { Sapma }}}$ \\
\hline Faktör 1: Aile Odaklılık & 170 & 3,60 & 0,732 \\
\hline Faktör 2: Modaya Düșkünlük & 169 & 2,89 & 0,826 \\
\hline Faktör 3: Sağlığa Düskünlük & 165 & 2,83 & 0,973 \\
\hline Faktör 4: Liderlik & 170 & 3,28 & 0,689 \\
\hline Faktör 5: Bakım & 170 & 3,74 & 0,705 \\
\hline Faktör 6: Kaygısızlık & 169 & 2,93 & 0,850 \\
\hline Faktör 7: Pratiklik & 169 & 2,26 & 0,678 \\
\hline Faktör 8: Zanaatkârlık & 165 & 2,54 & 1,018 \\
\hline Faktör 9: Toplum Bilinci & 170 & 2,81 & 0,853 \\
\hline Faktör 10: Maliyet Bilinci & 169 & 3,32 & 0,605 \\
\hline Faktör 11: Dișadönüklük & 163 & 3,38 & 1,029 \\
\hline Faktör 12: Maceraperestlik & 166 & 3,75 & 1,103 \\
\hline Faktör 13: Spora İlgi & 170 & 3,29 & 0,937 \\
\hline
\end{tabular}

Tablodaki ortalamalara bakıldığında en yüksek ortalamanın Maceraperestlik faktörüne ait olduğu $(3,75)$ en düşük ortalamanın ise Pratiklik faktörüne ait olduğu $(2,26)$ görülmektedir. Araştırmaya katılan Romanların maceraperest, bakıma (özellikle ev bakımı) dikkat eden ve aileye düşkün oldukları görülmektedir. Bununla beraber pratiklik (kredi kartı sahipliği ve hazır yiyecek kullanımı) konusunda düşük ortalamaya sahip oldukları yani pratik bir yaşam tarzını benimsemedikleri ifade edilebilir.

\subsubsection{Araştırmaya Katılan Kadın ve Erkek Romanların Yaşam Tarzı Tercihlerinin} Karşılaştırılması

Araştırmaya katılan kadın ve erkek Roman tüketicilerin tüketim eksenli yaşam tarzları arasında farklılık olup olmadığını ölçmek için tek faktörlü çoklu varyans analizi-MANOVA analizinden yararlanılmaktadır. Tek faktörlü çoklu varyans analizi (MANOVA), çok değişkenli analizler kategorisinde yer almaktadır. Bu kategorideki analizler için dikkat edilmesi gereken önemli bir nokta, analize alınacak örneğin hacmidir. Değişken sayısı ne 
kadar az olursa olsun, örnek hacmi 50 gözlemden az olmamalıdır (Nakip, 2006:176). Çok değişkenli varyans analizi (MANOVA), iki ya da daha fazla metrik bağımlı değişken varken kullanılmaktadır. Amaç, grup ortalamaları arasında fark olup olmadığını ölçmektir (Nakip, 2006:387). MANOVA uygulanırken 13 faktör bağımlı değişkenleri temsil etmektedir. Bağımsız değişken ya da gruplama değişkeni olarak cinsiyet belirlenmiştir. MANOVA ile kadın ve erkek Roman tüketiciler arasında 13 faktör bakımından bir bütün olarak farklılık olup olmadığı sonucuna ulaşılmaya çalışılmıştır. Demografik değişkenlerin yer aldığı Tablo 3'deki bilgilere göre araştırmaya katılan 118 erkek ve 72 kadın cevaplayıcı bulunmaktadır. Verilen cevaplar incelendiğinde 99 erkek ve 61 kadın cevaplayıcı analize uygun görülmüştür. Ayrıca yaşam tarzı karşılaştırmasında 56 ifade yerine 13 faktör dikkate alınmaktadır. MANOVA analizi uygulanırken Hotelling's $\mathrm{T}$ testi sonuçları \%5 anlamlılık düzeyine göre değerlendirilmiştir. MANOVA analizi ve Hotelling's $T$ testi sonucu Tablo 14'de gösterilmektedir.

Tablo 14: Araştırmaya Katılanların Cinsiyetlerine Göre Yaşam Tarzı Faktörlerinin Karşılaştırılması

\begin{tabular}{|c|c|c|c|c|c|}
\hline & \multirow[b]{2}{*}{ FAKTÖRLER } & \multicolumn{2}{|c|}{ Ortalamalar $^{1}$} & \multirow{2}{*}{$\underset{\text { Değ }}{\underline{F} \text { eri }}$} & \multirow{2}{*}{$\frac{\text { Anlamlılık }}{\underline{\text { Düzeyi }}}$} \\
\hline & & Kadın & Erkek & & \\
\hline 1 & Aile Odaklılık & 3,66 & 3,56 & $\overline{0,750}$ & $0,0,388$ \\
\hline 2 & Modaya Düşkünlük & 2,99 & 2,86 & 1,034 & 0,311 \\
\hline 3 & Sağlığa Düşkünlük & 2,78 & 2,83 & 0,092 & 0,762 \\
\hline 4 & Liderlik & 3,21 & 3,31 & 0,972 & 0,326 \\
\hline 5 & Bakım & 3,93 & 3,64 & 6,983 & $\underline{0,009}$ \\
\hline 6 & Kaygisızlık & 2,55 & 3,09 & 19,072 & $\overline{\mathbf{0 , 0 0 0}}$ \\
\hline 7 & Pratiklik & 2,16 & 2,30 & 1,466 & 0,228 \\
\hline 8 & Zanaatkârlık & 2,95 & 2,30 & 17,216 & $\underline{0,000}$ \\
\hline 9 & Toplum Bilinci & 2,68 & 2,87 & 1,987 & $\overline{0,161}$ \\
\hline 10 & Maliyet Bilinci & 3,46 & 3,23 & 6,469 & $\underline{0,012}$ \\
\hline 11 & D1şadönüklük & 2,98 & 3,63 & 16,859 & $\overline{0,000}$ \\
\hline 12 & Maceraperestlik & 3,58 & 3,85 & 2,306 & $\overline{0,131}$ \\
\hline \multirow[t]{2}{*}{13} & Spora İlgi & 2,85 & 3,51 & 22,272 & $\underline{0,000}$ \\
\hline & GENEL ORTALAMA & 3,06 & 3,15 & & \\
\hline Ho & F Değeri = 7,719 & Serbestlik Derec & $13 \mathrm{~A}$ & lılık D & eyi $=0,001$ \\
\hline
\end{tabular}

Araştırmaya katılan Roman tüketicilerin cinsiyetleri dikkate alınarak yapılan MANOVA analizi sonucuna göre kadın ve erkek katılımcılar arasında anlamlı bir fark olduğu görülmektedir (Hotelling's T Testi Anlamııık Düzeyi $=\mathbf{0 , 0 0 1 < 0 , 0 5}$ ). Araştırmaya katılan kadın ve erkek Roman tüketicilerin yaşam tarzı faktörleri bakımından birbirlerinden farklı olduğu ifade edilebilir. Bu farklılık hangi faktörlerde ortaya çıkmakta sorusunun cevabı olarak 6 faktörde farklılık olduğu tablodaki bilgilerden anlaşılmaktadır. Bu faktörler; Bakım, Kaygısızlık, Zanaatkârlık, Maliyet Bilinci, Dışadönüklük ve Spora İlgi şeklinde sıralanabilir. Fark çıkan faktörlerde ortalamalara dikkat edilirse Bakım konusunda kadınların erkeklere göre ortalama değerinin daha yüksek olduğu görülmektedir. Bakım faktörü altındaki ifadelerin daha çok ev temizliği, tertip ve düzeni ile ilgili olduğu düşünüldüğünde kadınların erkeklere oranla daha 
yüksek ortalama değere sahip olması, ev bakımına daha fazla önem verdikleri anlamına gelmektedir. Kaygısızlık faktörü incelendiğinde erkeklerin ortalamasının kadınlara göre daha yüksek olduğu görülmektedir. Bu faktör altındaki ifadeler özellikle ev temizliği konusundaki kaygıları belirtmektedir. Yine kadınların ev bakım ve temizliği konusundaki hassasiyetlerinin yüksek olması kadınların erkeklere göre daha düşük ortalama ile kaygısız yani daha kaygılı oldukları sonucunu ortaya koymaktadır. Zanaatkârlık faktöründe kadınların erkeklere oranla daha yüksek ortalamaya sahip olduğu ifade edilebilir. Bunun nedeninin bu faktör altında yer alan zanaatkârlık türünün terzilik ve dikiş dikme konusu olduğu için kadınların terzilik ve dikiş konularında erkeklere oranla kendilerini daha yatkın görmeleri olduğu söylenebilir. Maliyet bilinci faktöründe ortalamalar birbirine yakın çıkmıştır. Kadınların ortalamasının biraz daha fazla olduğu görülmektedir. Araştırmaya katılan kadınların yaşam tarzı bakımından erkeklere oranla maliyet bilinçlerinin biraz daha yüksek olduğu söylenebilir. Dişadönüklük konusunda erkeklerin ortalaması kadınlara göre yüksek çıkmıştır. Erkeklerin kadınlara göre yaşam tarzı bakımından daha dışadönük oldukları ifade edilebilir. Spora gösterilen ilgi konusunda yine erkekler kadınlara göre daha yüksek ortalamaya sahiptir.

\section{Sonuç ve Öneriler}

Türkiye'de farklı dil, din, ırk ve mezhepten topluluklar yaşamlarını sürdürmektedir. $\mathrm{Bu}$ farklılıklar bir arada yaşamın rengini oluşturmaktadır. Farklılıklarla hayatın anlamı ortaya çıkmaktadır. Farklılıklar ayrımcılığa neden olursa veya üstünlük ya da zayıflık göstergesi olarak değerlendirilirse bu durumda haksızlık ve zulüm meydana gelecektir. Romanlar Türkiye'de yaşayan etnik topluluklardan birisidir. Kendileri gibi toplum da onları renkli kişilikleriyle tanımlamaktadır. Bu çalışma Romanların kendilerine özgü yaşam tarzlarının tüketim eksenli olarak incelenmesini konu edinmektedir. Çalışmadan elde edilen sonuçlar şu şekilde sıralanabilir:

- Araştırmaya katılanların demografik bilgileri incelendiğinde erkek ve evlilerin çoğunlukta, ortalama gelirin asgari ücret düzeyinde ve eğitim seviyesinin büyük oranda ilk ve orta öğretim olduğu görülmektedir. Katılımcıların çoğunluğunun erkek ve evli olması Romanların erkek egemen bir topluluk oldukları ve erken evliliğin yaygın olduğu sonuçlarıyla örtüşmektedir. Ayrıca gelir düzeylerinin düşük olması, iş imkanlarının kısıtlılığı ile eğitim düzeylerinin düşük olması ise yine erken evlilik ve toplum tarafından dışlanma nedeniyle eğitim hayatlarının uzun olmaması şeklinde açıklanabilir. Araştırmaya katılanların meslekleri incelendiğinde serbest meslek ve müzisyen tercihinin daha ön planda olduğu görülmektedir. Eğitim düzeylerinin düşük olması, eğitim gerektiren mesleklerin görülmemesine neden olmaktadır. Romanların serbest meslek ve müzisyenlik tercihleri, kendilerini özgür ve eğlenceli görmeleriyle açıklanabilir. 
- Araştırmaya katılanlarda kredi kartı kullanımı yaygın olarak görülmemektedir. $\mathrm{Bu}$ durum düzenli bir gelirlerinin olmayışından kaynaklanmış olabilir.

- Araştırmaya katılanlar; Bursa şehrini trafik, ayrımcılık ve çevre kirliliği konularında sevmemekle beraber genel olarak Bursa'da yaşamaktan memnun olduklarını belirtmişlerdir. Bursa, nüfus bakımından Türkiye'nin dördüncü büyük kenti olarak farklı özellikte birçok insanın bir arada yaşayabildiği, anakent (metropol) özelliği taşıyan bir şehirdir. Bu durumun, Romanların Bursa'da yaşamaktan memnun olmaları sonucunu ortaya çıkardığı söylenebilir.

- Katılımcilara "Roman" deyince akla gelen 3 şey sorulduğunda; ilk iki sırada Ĕglence ve Renkli kavramları gelmektedir. Bu kavramları, Fakirlik, Cahillik ve Milliyetçi kavramları izlemektedir.

- Araştırmada Romanların tüketim eksenli yaşam tarzlarını incelemek için yaşam tarzı ölçeği olarak geliştirilen 56 ifadeli FİF (Faaliyet, İlgi Alanı, Fikir) Ölçeği kullanılmıştır. Araştırmadaki gözlem sayısı Faktör Analizi için uygun olmamaktadır. $\mathrm{Bu}$ nedenle literatürdeki bazı çalışmalarda FIF ölçeğine uygulanan Faktör Analizi sonucu 56 ifadeli ölçek 13 yaşam tarzı faktörüne indirgenmiş ve faktörler bu çalışmada da kullanılmıştır. 13 faktör bakımından Romanların yaşam tarzları incelendiğinde, en yüksek katılım maceraperestlik, bakım (özellikle ev bakımı) ve aileye düşkünlük faktörlerine çıkmıştır. Araştırmaya katılan Romanların maceraperest, bakıma (özellikle ev bakımı) dikkat eden ve aileye düşkün oldukları görülmektedir. Maceraperestlik, renkli ve eğlenceli kişilikleri ve özgürlüğü sevmeleri dolayısıyla Romanların yaşam tarzlarıyla örtüşen bir faktör olmaktadır. Faktörler içerisinde en düşük katılım ise Pratiklik (kredi kartı sahipliği ve hazır yiyecek kullanımı) ve Zanaatkârlık (terzilik ve dikiş dikme) yaşam tarzı bileşenlerine olmuştur. Araştırmaya katılan Romanlar genellikle kredi kartı kullanmamayı tercih etmektedir. Tablo 6'daki kredi kartı kullanım bilgilerine göre araştırmaya katılanların neredeyse yarısı $(\% 46,9)$ kredi kartı kullanmamakta, kullananların yaklaşık \%61'i tek kart kullanmaktadır. Zanaatkârlık olarak ise FİF ölçeğinde ağırlıklı olarak terzilik ve dikiş dikme ele alındığından dolayı ve Romanların uğraş alanlarının demircilik, kalaycılık, çalgıcılık, sepet işlemeciliği... vb. (Yükselsin, 2009) gibi terzilik dışındaki meslekler olması dolayısıyla katılımın düşük olduğu ifade edilebilir.

- Araştırmaya katılan Roman tüketicilerin cinsiyetleri bakımından yaşam tarzlarının karşılaştırılması amacıyla MANOVA uygulanmıştır. MANOVA sonuçlarına göre kadın ve erkek Romanların tüketim eksenli yaşam tarzlarının birbirinden farklı olduğu sonucuna ulaşılmıştır. Farklılık çıkan faktörler; Bakım, Kaygısızlık, Zanaatkârlık, Maliyet Bilinci, Dışadönüklük ve Spora İlgi şeklinde sıralanabilir. 
- Kadınların erkeklere göre yaşam tarzının Bakım, Kaygısızlık, Zanaatkârlık ve Maliyet Bilinci faktörlerine daha yüksek katılım sergiledikleri görülmektedir. Kadınlar özellikle ev bakımı açısından daha duyarlı, kaygısızlık bakımından daha az kaygısız yani daha kaygılı, zanaatkârlık (terzilik) bakımından daha zanaatkâr ve maliyet bilinci yönüyle de daha bilinçli bir yaşam tarzı belirlemektedir. Bakım faktörü altındaki ifadelerin daha çok ev temizliği, tertip ve düzeni ile ilgili olduğu düşünüldüğünde kadınların erkeklere oranla daha yüksek ortalama değere sahip olması, ev bakımına daha fazla önem verdikleri anlamına gelmektedir. Kaygısızlık faktörü incelendiğinde erkeklerin ortalamasının kadınlara göre daha yüksek olduğu görülmektedir. Bu faktör altındaki ifadeler özellikle ev temizliği konusundaki kaygıları belirtmektedir. Yine kadınların ev bakım ve temizliği konusundaki hassasiyetlerinin yüksek olması kadınların erkeklere göre daha düşük ortalama ile kaygısız yani daha kaygılı oldukları sonucunu ortaya koymaktadır. Zanaatkârlık faktöründe kadınların erkeklere oranla daha yüksek ortalamaya sahip olduğu ifade edilebilir. Bunun nedeninin bu faktör altında yer alan zanaatkârlık türünün terzilik ve dikiş dikme konusu olduğu için kadınların terzilik ve dikiş konularında erkeklere oranla kendilerini daha yatkın görmeleri olduğu söylenebilir. Maliyet bilinci faktöründe ortalamalar birbirine yakın çıkmıştır. Kadınların ortalamasının biraz daha fazla olduğu görülmektedir. Araştırmaya katılan kadınların yaşam tarzı bakımından erkeklere oranla maliyet bilinçlerinin biraz daha yüksek olduğu söylenebilir. Dişadönüklük konusunda erkeklerin ortalaması kadınlara göre yüksek çıkmıştır. Erkeklerin kadınlara göre yaşam tarzı bakımından daha dışadönük oldukları ifade edilebilir. Erkekler çalışma zorunluluğu ve meslek şartları gereği daha dışadönük olmak durumundadır. Özellikle eğlence sektöründe çalışan Romanların daha sosyal ve dişadönük olmaları mesleklerinin gereği durumundadır. Kadınların erken yaştaki evlilik sonrası ev ve çocuk bakımı dolayısıyla daha kapalı bir yaşam içerisinde olmaları olağan karşılanabilir. Spora gösterilen ilgi konusunda yine erkekler kadınlara göre daha yüksek ortalamaya sahiptir.

$\mathrm{Bu}$ çalışma Bursa şehir merkezinde yaşayan Roman vatandaşlar örnekleminde ve belirli bir tarihte uygulanan bir nicel araştırma yöntemi (anket) aracılığıyla veri toplanarak gerçekleştirilmiştir. Gelecekte farklı popülasyonlarda, farklı zaman ve mekanlarda, nitel ve nicel araştırma yöntemleri kullanılarak keşfedici ve tanımlayıcı (betimsel) araştırmalar yapılabilir. Ayrıca bu çalışmada FİF (Faaliyet, İlgi Alanı, Fikir) Ölçeği kullanılmıştır. Gelecekteki çalışmalarda farklı ölçekler kullanılarak daha farklı sonuçlar elde edilebilir. 


\section{KAYNAKÇA}

Atilgan, T. (2003). Ege Üniversitesi Öğrencilerinin Tekstil Ürünlerinin Markaları Hakkındaki Görüşleri Üzerine Bir Araştırma, Ege Akademik Bakış Dergisi, Cilt: 3, Sayı: 1-2, 90-118.

Erciş, A, Ünal, S. ve Can, P. (2007). "Yaşam Tarzlarının Satın Alma Karar Süreci Üzerindeki Rolü’, Atatürk Üniversitesi IIBBF Dergisi, Cilt No:21, Sayı: 2, 281-311

Erdal, M. (2001). "Yaşam Tarzı Analizi ve Psikografik", Pazarlama Dünyası, Yı1:15, Say1:89, Eylül-Ekim 2001, s:36-42.

Eryiğit, C. ve Kavak B. (2008). "Yeniliği Erken Ve Geç Benimseyenler İle Benimsemeyenlerin Demografik Özelliklerinin Ve Yaşam Tarzlarının Yayılma Modelleri Yardımıyla Tanımlanması", Pazarlama ve Pazarlama Araştırmaları Dergisi, Sayı: 03, Aralık 2008, ss. 21-43

Foxall, G. R., Goldsmith, R. E. ve Brown, S. (1998). Consumer Psychology For Marketing, Second Edition, Thomson Learning, London.

İslamoğlu, A. H. ve Altunışı, R. (2013). Tüketici Davranışları, Beta Yayınları, İstanbul.

Karafakioğlu, M. (2006). Pazarlama İlkeleri, Literatür Yayınları, İstanbul.

Kavak, B. ve Gümüşlüoğlu L. (2007). Segmenting Food Markets: The Role of Ethnocentrism and Lifestyle In Understanding Purchasing Intentions, International Journal of Market Research, Vol. 49 Issue 1, pp. 71-94

Kotler, P. (2001). Principles of Marketing, Prentice-Hall International Inc., New Jersey

Kotler, P. ve Armstrong, G. (1996). Marketing an Introduction, Prentice Hall International Inc., Upper SAddler River, New Jersey.

Kotler, P. ve Armstrong, Gary (2014), Principles of Marketing-Global Edition, 15E, Pearson Education Limited, England

Köroğlu, C. Z. (2014). "Tüketim Kültürü Ve Din Olgusu Üzerine Uygulamalı Bir Araştırma”, Toplum Bilimleri Dergisi, Ocak-Haziran, 8 (15): 85-120

Küçükemiroğlu, O. (1999). Market Segmentation by Using Consumer Lifestyle Dimensions and Ethnocentrism: An Empirical Study, European Journal of Marketing, Vol. 33, No. 5/6, 1999, pp. 470-487

Malhotra, N. K. ve Birks, D. F. (2006). Marketing Research, an Applied Approach, Prentice Hall, Financial Times, England.

Nakip, M. (2006). Pazarlama Araştırmaları Teknikler ve (SPSS Destekli) Uygulamalar, 2. Baskı, Seçkin Yayınları, Ankara. 
Odabaşı, Y. ve Barış, G. (2010). Tüketici Davranışı, MediaCat Yayınları, İstanbul.

Odabaş1, Y. (1999). Tüketim Kültürü, Yetinen Toplumun Tüketen Topluma Dönüşümü, Sistem Yayınları, İstanbul.

Özsoy, M. (2014). "Roman Vatandaşların Satın Alma Davranışlarının Araştırılması", Yayımlanmamış Yüksek Lisans Tezi, Süleyman Demirel Üniversitesi Sosyal Bilimler Enstitüsü, Isparta.

Parası, İ. (2014) İktisadın ABC'si, Ezgi Kitabevi, Bursa..

Solomon, M. R. (1996). Consumer Behavior Buying, Having and Being. Prentice Hall International Editions, Third Edition, New Jersey.

Solomon, M., Bamossy, G., Askegaard, S. ve Hogg, M. K. (2006). Consumer Behaviour A European Perspective, Third Edition, Prentice Hall, Financial Times, England.

Tek, Ö. B. ve Özgül E. (2013). Modern Pazarlama İlkeleri, 4. Baskı, İzmir, Birleşik Matbaac1lık

Yeşiloğlu, H. (2013). "Yaşam Tarzının Müşteri Sadakati Ve Tüketicilerin Satın Alma Davranışları Üzerine Etkileri: Organik Gıda Ürünlerini Kullanan Tüketiciler Üzerinde Bir Uygulama", Yayımlanmamış Yüksek Lisans Tezi, Atılım Üniversitesi Sosyal Bilimler Enstitüsü, Ankara.

Yükselsin, İ. Y. (2009). "Satılık Havalar: Batı Türkiye Roman Topluluklarında Bir Müziksel Zanaatkârlık Biçimi Olarak "Çalgıcılık"”, Uluslararası Sosyal Araştırmalar Dergisi/The Journal of International Social Research, Volume 2/8, Summer 2009, ss.452-463

http://www.bursa.com.tr/

http://www.yenidonem.com.tr/yazar/n-nuri-yavuz/bursa\%E2\%80\%99da-trafik-veyonetimi/1755.html, 